\begin{tabular}{c|c|c} 
Issues in & $\begin{array}{c}\text { Informing Science }+ \\
\text { Information Technology }\end{array}$ & $\begin{array}{l}\text { An Official Publication } \\
\text { of the Informing Science Institute } \\
\text { InformingScience.org }\end{array}$ \\
\hline INSTITUTE & InIT.org
\end{tabular}

Volume 14, 2017

\title{
INNOVATING AND ENTREPRENEURIAL INITIATIVES: SOME CASES OF SUCCESS
}

\author{
Marta Machín-Martínez \\ Universidad Rey Juan Carlos, martamachin94@gmail.com \\ Madrid, Spain \\ Carmen de-Pablos-Heredero* \\ Universidad Rey Juan Carlos, Carmen.depablos@urjc.es \\ Madrid, Spain \\ * Corresponding author
}

\section{Abstract \\ Aim/Purpose \\ Background \\ Methodology \\ Contribution}

Findings

Recommendations for Practitioners
To understand the change of entrepreneurial initiatives by analysing some new initiatives that came up the last years based on IT enabled business models The theme is described from an educational perspective by offering examples of successful entrepreneurship initiatives

Description of some cases: Waynabox, Lock up, Uber, Pinterest

This project tries to become a guide for youth in order to understand various aspects: first, the entrepreneurial aspects that have to be considered before starting a business; secondly, the characteristics that successful businesses have in common; and finally how an entrepreneur can be innovative and how they can achieve the success

Only the $10 \%$ of the start-ups exist more than three years. Among the causes of failure are the high saturation of the market and the market competition, which are connected to the ignorance of the real necessity of customers.

The company has to identify the needs of customers. They have to define and target their customers by observing and analyzing the market and, above all, getting in touch with the customers.

The business plan is something that has to be carried out before the beginning of the project, and has to exist on paper. Everything has to be planned and organised, and the objectives have to be clearly stated in order to stay focused

To use existent business models as an inspiration for the creation of a new business model. It is really important to avoid copying the business model itself. One thing that a company needs to do is to make the difference offering new characteristics adapted to the current customer's experiences

Accepting Editor: Eli Cohen | Received: December 1, 2016 | Revised: March 16, 2017 |

Accepted: March 28.

Cite as: Machín-Martínez, M., \& de-Pablos-Heredero, C.. (2017). Innovating and Entrepreneurial Initiatives:

Some cases of success. Issues in Informing Science and Information Technology Education, 14, 139-161. Retrieved from http://www.informingscience.org/Publications/3717

(CC BY-NC 4.0) This article is licensed to you under a Creative Commons Attribution-NonCommercial 4.0 International License. When you copy and redistribute this paper in full or in part, you need to provide proper attribution to it to ensure that others can later locate this work (and to ensure that others do not accuse you of plagiarism). You may (and we encourage you to) adapt, remix, transform, and build upon the material for any non-commercial purposes. This license does not permit you to use this material for commercial purposes. 
Recommendation It is really important to have a good relation with the customer, to attend their for Researchers needs and to help them with all the doubts that they can have about the company.

An entrepreneur cannot be guided by his own interests. He has to invest in order to know the needs of the potential customers

Impact on Society Customer experience is key to have success in new business models

Keywords entrepreneurial initiatives, case study, customer experiences, knowledge society

\section{INTRODUCTION}

In this paper entrepreneurial initiatives from an historical point of view are analysed, showing how the meaning of the term entrepreneurship has changed over time. The objective of the project is to understand the change of entrepreneurial initiatives by analysing some new initiatives that came up the last years. Two companies that started in 2008 as startups are going to be considered as they have become successful businesses. This paper tries to become a guide for the youth in order to understand various aspects: first, the entrepreneurial aspects that have to be considered before starting a business; secondly, the characteristics that successful businesses have in common; and finally how an entrepreneur can be innovative and how they can achieve the success.

First of all, in order to understand the whole concept of entrepreneurial initiatives we need to analyse the meaning of the words "entrepreneur" and "initiative" throughout their history.

An entrepreneur is by definition "someone who starts their own business, especially when this involves seeing a new opportunity" ("Entrepreneur," 2016).

An initiative is by definition "a new plan or process to achieve something or solve a problem" ("Initative," 2016).

Making an analysis through the history, the term "entrepreneur" was first detailed by Richard Cantillon, an Irish-French economist who introduced it as a "risk taker" in the essay "Essai sur la nature du commerce en general' (Cantillon, 1755). This term came into wider use after John Stuart Mill popularized it in "Principles of political economy" (Mill, 1973).

We can see the evolution of the term of "entrepreneurial initiative" by analysing the different meaning through the years.

"The entrepreneur buys products under a determined price in the present, he combines them in a good way in order to obtain a new product and then he sells it under uncertain price in the future. He has to assume present risks and uncertainty in the market" (Cantillon, 1756).

The concept of "entrepreneur" involves current economic markets, because the economic markets are the field of work where the entrepreneur will have to develop his ideas. The concept was firstly introduced by Frank Hyneman Knight. Knight was an American economist who worked on theories of risk, value, and profit. He said that the entrepreneurs try to predict the changes in the markets and they act depending on them. The entrepreneur bears the uncertainty of the market dynamics (Knight, 1921).

The next evolution of the definition introduces the concept of "implementing change" as compulsory for an entrepreneur. Schumpeter (1934) was the first economist that developed the idea. He was a professor at Harvard University and he said that the entrepreneur is an innovative person who implements change in the markets through the enforcement of new combinations that take several forms. An entrepreneur can introduce a new product or a new quality of the same product making it new. An entrepreneur can also introduce a new method of production in order to innovate. An entrepreneur can be open to new markets in order to extend their production. An entrepreneur can also overcome a new source of supply of materials or parts, in order to take advantage from the competi- 
tion. And finally an entrepreneur can also create a new organization or reorganize an existing organization in order to improve it.

The change in the term entrepreneur comes along with another important concept, opportunity. Innovation involves opportunities. On the one hand, we have an entrepreneur that has a business idea, understanding the idea as an intuition, an observation, and a chance that makes the person see the possibility to open and develop a business. On the other hand, we have the opportunity, that is a favourable given situation in the markets and therefore in the external environment, that can help the entrepreneur to develop the idea. Kirzner (1979) was the first one who made a relation between entrepreneur and opportunities. "The entrepreneur recognizes opportunities and takes action in order to seize them. It is the one who has skill to take advantage of market imperfections".

Historically the concept of entrepreneur was also linked to the creation of companies. Gartner is an American Professor of entrepreneurship who was one of the pioneering entrepreneurship research scholars in the 1980s and he was the one who developed this idea. "The entrepreneur is the one who creates new companies" (Gartner, 1985).

In 2000 the study of entrepreneurial innovation is frequent in order to take advantage of market opportunities. "The entrepreneurship includes the study of sources of opportunities, the processes of discovery, the evaluation and exploitation of opportunities, and the people who discover, evaluate and exploit them. The entrepreneurship does not require, but may include, the creation of new organizations" (Shane \& Venkataraman, 2000).

The European Commission developed two definitions of entrepreneurship in 2003 and 2004 that agree with the current knowledge when we think about entrepreneurial initiatives. "The entrepreneurship is the attitude and process that creates and develops an economic activity, combining risktaking, creativity and/or innovation with management, in a new or existing organization. The entrepreneurship is, above all, a way of thinking or mentality. It includes the motivation and the ability of the individual, either independently or within an organization, to identify an opportunity and fight for it and, in that way, produce new value or economic success" (European Commission, 2004).

"The entrepreneurship includes the propensity to induce changes in oneself, the ability to accept and support innovation brought about by external factors, to welcome change, to take responsibility for one's actions (positive or negative), to finish what you start, to know in which direction your project is going, to set goals and achieve them, and to have the necessary motivation for success" (European Commission, 2004).

The entrepreneur initiative is, in its broadest sense, one of the basic skills (European Commission, 2004) to ensure that the European Union is "the economy based on the most competitive and dynamic knowledge of the world, capable of sustainable economic growth with more and better jobs and with greater social cohesion".

As we can see it has been a progression of the idea of "entrepreneurial initiative" including the concepts of motivation and innovation (concepts that arise in the last decades) besides from just taking risks and analysing the economic markets and issues. Today the concept includes all these dimensions: risk-taking, motivation, and innovation.

In order to become an innovative and motivated entrepreneur one needs to have some skills and aptitudes that will help in developing a business idea successfully.

There are seven main skills or attributes that an entrepreneur should have. One of the most important abilities is the capacity to make decisions and take risks. This does not mean to be reckless. The entrepreneur must keep a cool head knowing the risk that he is assuming. Also important are the use of creativity and the desire for innovation. The entrepreneur should have brilliant ideas and find new solutions for existing problems. In addition, he has to be willing to take on new challenges. Another important skill is that he must be self-confident. An entrepreneur must be convinced that he will succeed and he should be motivated to achieve the goals. He will certainly have failures, but he 
has to know that sooner or later he will reach success. He must be practical; he should go to the point in order to maximize the time. He has to be organized; in any business activity the order and consistency are fundamental. He has to be able to make relationships. An entrepreneur is never alone. His success depends largely on others (customers, partners...). As we know, success is not immediate, but the entrepreneur must pursue with patience the goals and have enough capacity to maintain himself calm despite the uncertainty (Patel, 2015).

There are many investigations about what young people should study before going to the university in order to motivate them to be entrepreneurs. One of the most famous forums is the one that takes place in Lyon (France) almost every year called "World Entrepreneurship Forum". This Forum brings together over 80 international entrepreneurs, social entrepreneurs, and politicians, as well as academics working in the field of entrepreneurship. The forum has a guiding principle: "entrepreneurs are creators of wealth and social justice: long-term and sustainable prosperity for all will depend, in large part, on their imagination, courage, energy, and skills" (Encouraging social and commercial entrepreneurship, 2009). In this forum, the motivation for the entrepreneurial initiatives and the enthusiasm for a global entrepreneurship community can be seen.

The Director of the Centre for Entrepreneurship and Public Policy of the George Mason University in the United States, Zoltan Acs, said in 2009 that the forum was the first organization to combine social justice and wealth in a global context (Encouraging social and commercial entrepreneurship, 2009). One of the main conclusions that we can find out in the forum is that young people should study some specific concepts related to entrepreneurship before going to the university. The point is that young people should be prepared to become entrepreneurs without studying a specific business degree or course. If they want to create a business in the future, they need to have the essential skills and knowledge in order to succeed. Most of the companies created don't survive the first couple of years. Here you have the concepts that were decided in the forum as mandatory entrepreneurial concepts that should be studied before university:

- The most important relationship you'll have with anyone in your life is what you have with yourself, so treat yourself well.

- Train your mind to see opportunities where others see obstacles.

- Young people think about how they will make millions. The idea is to think about how they sell a unit of product or one hour of service and make enough profits.

- Look for a business advantage and the best business model.

- Most of the wealth is created through creating business opportunities.

- If you listen to your customers and ask the right questions, they will tell you their needs.

- Every great business leader is aware of the community around him and seeks to satisfy its needs.

- It is important to understand the investments of time, energy, and money. You invest them because you believe that someday your company will gain more energy, time, and money than you have put into it. The breakeven point is important because it will let you know if you can afford your marketing plan.

- By identifying the needs of consumers, a young person can educate the customers about the benefits of his product or service.

- Putting your visions and dreams in writing improves your chances of success.

- It is important to consider a method for estimating how many years it takes to double your investment. 


\section{Analysis of InNOVATIVE Projects}

Every year worldwide a lot of new companies are created. Many entrepreneurs have an idea that has been never developed, or they want to renovate an existing idea, and they try to take advantage of the market opportunities establishing their projects. The paper explains to students IT enabled models. It helps in promoting education so that entrepreneurs are motivated to create firms.

We are going to describe some innovative projects that we have found of interest and that have been created in the recent years in the Spanish market. The examples are all of tech companies as it may be different for another sector that does not predominately rely on tech. They are all IT enabled models.

\section{WAYNABOX}

Waynabox is a startup, a company that is just beginning to be developed. A startup company is usually small and initially financed and operated by a handful of founders or one indi-

\section{? waynabox} vidual (Fontinelle, 2012).

Three engineer friends created Waynabox in 2015. The idea of creating a company came up when they were interrailing together after finishing their university degree; their eagerness to travel and see the world gave them the idea to set up their own business in Spain. The first idea was to create something similar to Interrail but replacing trains with planes, but the fact is that Waynabox has been more innovative (Centrodeinnovacionbbva.com, 2016).

For this analysis Oriol Esteban, Invoice master of Waynabox, was interviewed; he answered our questions by mail and sent us some documents with information about the company.

\section{Service at Waynabox}

The service includes 4 steps. The client picks some dates, the system shows the price, but the destination is unknown.

In the first step you as a client have to choose the dates. The traveller visits www.waynabox.com and selects the dates he wants to travel. Each package has a fixed price, regardless of the date of the trip or the final destination. In this way, in the first step you can have an idea of the final price of your trip. In the second step you have to choose the possible destinations. After the first selection the traveller will see the list of the possible destinations. This list will change every month and it will have different destinations, so you will never find the same cities if you want to repeat. In this step the traveller will unselect those destinations where he does not want to travel; the first unselection is free and if you want to do more it will cost $5 €$ each one. And that is all the process. The fourth step deals about discovering where you are flying, because you will have to pack and you do not know where you are going. The traveller will discover where he is travelling 48 hours before the departure. The price includes both round trip flights and the two first nights in a Wayna approved accommodation (Waynabox, n.d.).

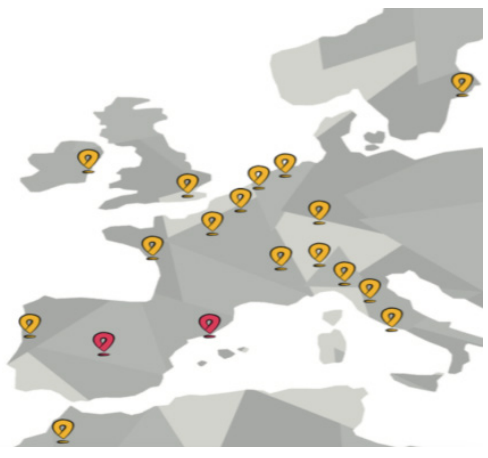

To sum up, the reservation includes the accommodation (opaque pricing). In this way the target customer is one who will purchase the service primarily based on the price and not based on the company's amenities. The hotels are very carefully selected by the Waynabox Team. All of them have at least a rating of 3.5 over 5 or more in TripAdvisor and are located near the centre of the city (Waynabox, 2016).

The startup organizes travel arrangements, including round-trip flights and 2 night's hotel accommodation, at a set price of $150 €$ 
per passenger (minimum 2 people). The catch is that users have no idea of their destination until 48 hours prior to departure (Waynabox, 2016).

\section{Price}

You have to pay $150 €$ for the whole package of flights plus accommodation. But if you want to unselect more cities you will be charged with $5 €$ each time. This low price is granted by the opaque pricing. Opaque pricing is a way that companies can sell their products or services at hidden, lower prices. It is a type of price discrimination; the target customer is the one who will purchase a service based on price and not on the company's amenities or reputation. It is a pricing strategy that charges the customer the maximum price that he is willing to pay, in this case $150 €$ (Page, 2015).

Also if you are not time flexible you are able to arrange the departure at a certain period of time, but you will be charged $10 €, 20 €$ or $30 €$.

\section{Innovation}

"Normally when you travel the first thing you think about is the destination and then you organize the trip itself. But with Waynabox it's completely different." (Centrodeinnovacionbbva.com, 2016).

They are growing non-stop; they recently added Malaga Airport as a starting point, which means that the low-cost opportunity to flying and seeing the world appeals to people.

There are many loyal users, so the company invites them to post photos with destinations that they would like to go and in exchange the company offer a ten euro discount on their next trip (Centrodeinnovacionbbva.com, 2016).

The biggest benefit is the wow factor. Young people have travelled more and they have experienced a lot of adventures so it is really difficult to surprise them. With Waynabox they have the feeling and the evidence that they don't know where they are travelling.

\section{Target}

The company's target market is young people aged 25 to 35 years of age, but it is not unusual to see entire families traveling with grandparents and children too.

Waynabox is attractive for a market segment that is used (or would like to) travel spontaneously. They are young digital travellers, used to new technologies, online bookings, and processes made simple.

Waynabox is an entity member of ISIC, the UNESCO student international representation organization, which adds direct value to more than 13 million students in Europe. And they also have the support of the airline TAP Portugal (Lanzadera aceleradora empresas, 2015; TAP Portugal, 2016).

They had 8,193 passengers in the first 6 months of operation, which is a surprisingly number of people if we take into account that the company was in the first stage of consolidation into the market. Waynabox has generated 1,389,000€ of revenue for hotels and airlines in 2015. And they have experienced a growth in sales of $26 \%$ month by month. If we analyse their figures we can see that they are growing and establishing themselves successfully in the market. (Lanzadera aceleradora empresas, 2015)

\section{Initial Investment}

Waynabox was one of the winners of the second edition of Lanzadera, funded by Juan Roig. Lanzadera is a Spanish initiative to promote the creation of new firms. In the summer of 2015 Waynabox received an external economic investment of 250,000€ (Lanzadera aceleradora empresas, 2015). That was their total initial investment. 


\section{Survey}

One of the most difficult things to do once you graduate is to create a business. Oriol explained that for their aeronautic engineer degree the usual procedure is to develop an airline while you are in the university. But they had to move from that project because of the big investment that is necessary. The thing that helped them the most was winning the Lanzadera (Waynabox, 2016).

When you want to create a business the biggest problem for engineers and other students is the bureaucracy, without any doubt. Spain is not a startup-friendly country, and the advice that Oriol wants to offer to young people is that if they have an idea, don't let it go - try it. "You make more value by trying with your biggest effort than working 10 years for a big company without promotion"

(Waynabox, 2016).

Another thing they know that it is not working is the business education in Spain. Oriol said that they would have appreciated basic knowledge in taxes and management before university. He is also in favour of business educational programs before university (Waynabox, 2016).

\section{BARBIKU}

\section{Service}

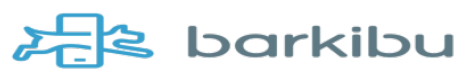

Barkibu is an app for mobile devices and a webpage that allows pet owners to make online consultations with professional veterinarians. Veterinarians improve the support to their customers in an easy and secure way, they gain web presence, and they reach potential customers through the platform (Barkibu, 2016). The veterinarians are grouped in a ranking named "the best veterinarian" where the customers can rate them and give opinions about them. A customer can filter the search by approximation, price, personal opinions, response rate or speciality (YouTube, 2016).

The mission of the company is to provide care to pets around the world. They try to educate to owners about the care of the animals by putting them in contact with veterinary professionals quickly and easily. They offer professional veterinary advice; the responsibility of Barkibu is to ensure that only veterinarians give advice through the platform. They also report animal abuse (BARKIBU, 2016).

Barkibu offers in its website a section where you can adopt pets. People put there the pictures and information of the pets and you can adopt them. If you adopt you will be given 3 months of free Barkibu service (Barkiadopta.org, 2016).

They are proud of their company, a dog-friendly company. They show their dogs in the webpage as "support team," and they go to the office everyday with them.

Nowadays they have more than 5,000 monthly consultations and more than 1,600 veterinarians registered and they will continue growing (Lanzadera aceleradora empresas, 2016).

\section{Price}

Barkibu is a start-up that tries to cover part of the existent needs. On this site, users can make online consultations to veterinarians for free. Everybody wins: the customers receive a comfortable and free service where they will be answered within 72 hours and the veterinarians who are in this marketplace are going to gain visibility. They will be able to have more customers in their clinics and retain their existing customers. There is a premium pack option, you can pay $4.99 €$ for a consult and you will be answered within 2 hours in case of extreme urgency. If you are not happy with the answer they will return the money (BARKIBU, 2016). 


\section{Innovation}

The project meets the needs of customers. The three partners have a pet, and they realized that they often have a question for which it is not worthwhile to go to the veterinarian but they were willing to pay in order to know the answer at that moment. They have completely reinvented the concept of going to the veterinarian. They are now offering to the customer the possibility of answering their doubts about their pets without going out of home.

\section{Target}

The marketplace for this company is bigger than you can imagine. In Spain there are 5.5 million dogs, 4 million cats, and the number is increasing day by day. The business opportunity reaches 1,270 million euros, and the most part (about 887 millions) are bounded to purchase food. Globally, only food for dogs and cats is an opportunity of more than 20,000 million euros and it is growing about 3\% and 5\% annually (Arrieta, 2015).

Barkibu is working with the current model since February 2015. Until then, they offered a pay system per visit, which didn't get the attraction they expected. "Our current goal is to grow, both in Spain and abroad" said Pablo Pazos, CEO of Barkibu, he revealed: "we are currently growing over 50\% month to month" (Arrieta, 2015).

\section{Investment}

The startup was involved in the Lanzadera project. "It was in that period when we decided to refocus the business model," said Pazos. The 310,000 euros achieved in the round of funding have been provided mostly by the Esade BAN network. The valuation of the company has not been disclosed. This investment is in addition to the 100,000 euros raised in its first round a year ago, and 200,000 euros from Looper, in the form of loans (Arrieta, 2015).

\section{LOCKUP}

\section{Service}

Lock Up is an access control and management system for hotels. Its novelty for innovation is that guests can access their rooms using their cellphones as well as other methods. Besides it can be

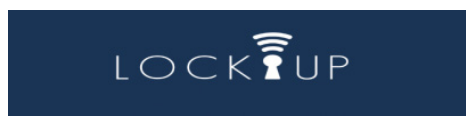
installed in bars and restaurants, ballroom or event rooms, fitness facilities, swimming pools as well as in hotel parking facilities (Lock Up, n.d. a).

It is an innovative product that allows you to modernise a hotel just by installing a simple device that transforms passive units, like the doors, into active units that will give information to optimise the resources. The device allows warehousing information on guest's times, consumption habits, energy use, etc. In addition, it can work as a marketing tool to offer guests other hotel services (Lock Up, n.d. a).

With Lock Up the clients will access their rooms with their smartphones. No key card is necessary. They could manage and plan everything in their rooms, being able to make a "do not disturb" request without moving just using their Mobile App (Lock Up, n.d. a).

The hotel can start monitoring rooms and facilities in real time as well as create a direct channel with customers to offer hotel services and customised services with Lock Up Marketing Tool. Lock Up will monitor the rooms at any time confirming if a client has arrived, if a room has been cleaned... The guests will be able to open their doors just using their smartphone in any part of the room. If they are in the bathroom they could open the door to whoever they want. The hotel can contact the guests from reception desk in a direct non-invasive way sending messages to inform them of phone calls that they have received or relevant information from them. The hotel can also programme a welcome message for the guests upon arrival to their rooms. It can also include relevant information 
of how to use the facilities and any tips for their stay. The guests will also be able to contact reception desk at anytime and anywhere free of charge (Lock Up, n.d. a).

Lock Up allows its guests to access parking facilities without going to reception desk. They just need to open the parking facilities barrier using the Mobile App. Once inside the system will assign a space and inform the reception desk that the guest has arrived so as to prepare their check-in. The hotel can manage the parking facilities giving, denying, and blocking access. With the App the guest can also get access to the buffet service and to event rooms, receive a beginning and ending alert, and finally book the buffet service in advance. Any client will be able to know hotel facilities and services available before arriving. For example, they can get information about a fitness area of the hotel, and they can reserve a service or find out about hotel promotions and offers (Lock Up, n.d. a).

The management of the hotel will also be improved. Both temporary and permanent workers will be able to access only those areas that are appointed to them, workers will be able to inform on technical issues, once solved, they will mark them as being fixed (Lock Up, n.d. a).

The hotel will take advantage of a fast check-in having access to client's information even before they arrive, including ID or Passport. The hotel can offer a Premium Check-in sending a "digital key" directly to the client's smartphone. In this way, the guests could access their rooms and park without going to reception desk, making their stay more productive. The hotel can also deal with the complaints by having a discrete channel of communication solving the issues and preventing them from becoming public (Lock Up, n.d. a).

\section{Security System:}

Lock $\mathrm{Up}$ is a robust and secure system since all flow of information is end-to-end encrypted in AES128 (Lock Up, n.d. b).

An end-to-end encryption is a system of communication where only the communicating users can read the messages. End-to-end encryption ensures only you and the person you're communicating with can read the information that is sent, and nobody in between. The messages are secured with a lock, and only the recipient and you have the special key needed to unlock and read the message (Lock Up, n.d. b).

Furthermore, since locks are not online, they cannot be hacked remotely. There is no remote access to them. This characteristic makes them extremely safe. Lock up information sent to the server is also secured with end-to-end encryption (Lock Up, n.d. b).

\section{Innovation:}

This product is completely innovative because they take advantage of the new technologies in order to exist. The company takes for granted that everybody has a smartphone with internet connection, and they offer the possibility to make the hotel accommodation as pleasant as possible.

One of the most important things from this product is that the hotel does not need to change the locks, they just need to update them. In 5 minutes, a Bluetooth device is installed inside the lock. The system starts working alongside the existing system. Both systems can work at the same time without interfering with each other (Lock Up, n.d. b).

\section{Target}

The company looks for hotel chains that want to use their product by merging their actual system and the new one. In October of 2015 the system was being implemented in 4 Spanish hotel chains and they took part of the Hotel Fair Interihotel.

Hotel chains know that in their marketplace they have to renew every so often or die. They are looking for new ways to adapt new technologies, making a difference between the competitors. In Spain 
we found more than 200 chain hotels with more than 3,800 hotels and more that 860,000 rooms, and we are not taking into account the independent hotels that represent a small part of the marketplace.

\section{Initial Investment}

Lock Up was presented in the third edition of the Lanzadera Project launched by Juan Roig and they received their full initial investment by private investors which were not disclosed.

\section{ANALYSIS OF SUCCESSFUL START-UPS}

The arduous path that an entrepreneur has to follow when creating a new company is tough, undefined, and blurry. But there are entrepreneurs that started with an idea and they have actually a successful business. I am going to analyse a view through the history of two companies that started few years ago as start-ups and they are successful businesses nowadays, Uber and Pinterest.

\section{$U B E R$}

"Uber is for sure not only a private chauffeur entity. In fact, it is a logistics company, and its stunt with ice cream delivery, flower delivery and helicopters on demand is an example of how you can do whatever you want once you have the right application for it, and once enough people are using it" (Belarbi, 2014).

The timeline of Uber is going to be described in order to explain how they developed the business idea, when they received the funding needed for developing the project, who invested in the company a,nd how they faced all the problems that emerge.

The story of Uber starts in 2008 when the co-founders were attending LeWeb conference in Paris. Travis

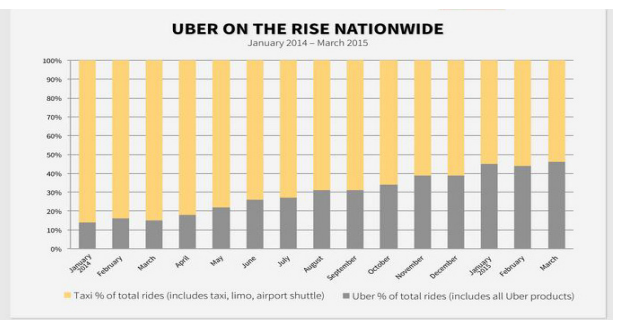
Kalanick and Garret Camp were complaining about finding a cab when they were with luggage under the rain and no taxi seems to pass by. Then the two friends started brainstorming, thinking about ways to solve the global issue of finding cars at the right place, on the right time. They decided that the solution had to be mobile and fast (Uber.com, n.d.).

Garett Camp started to prototype several solutions and engineering a mobile app for iPhone. It didn't take long before Travis Kalanick joined the ride to work with him on what would later be known as

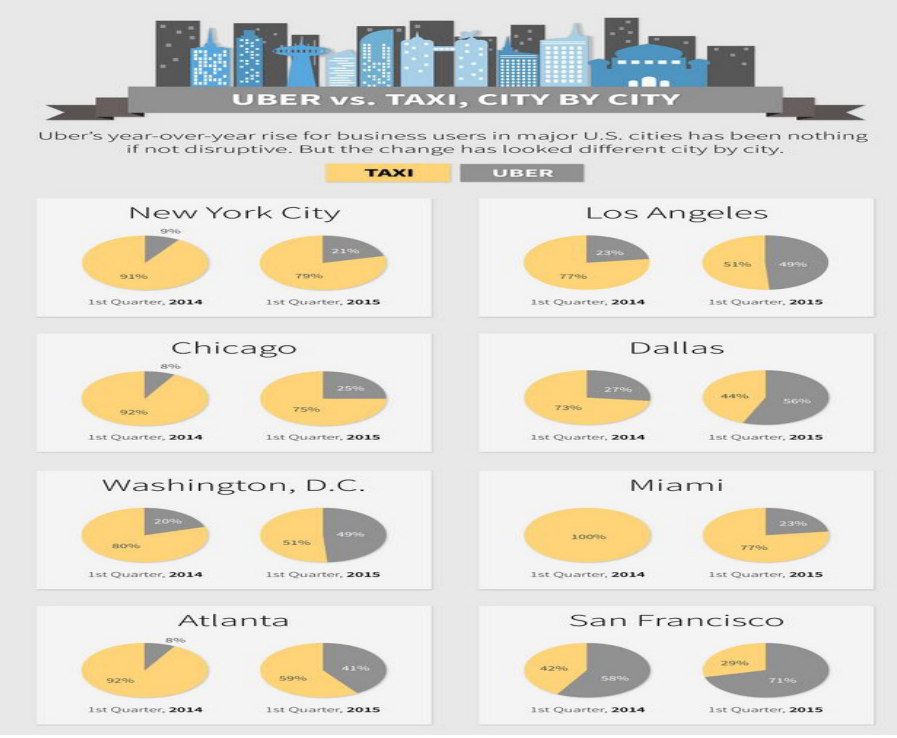
Uber. In January 2010 Uber was already rolling a couple of black cars in the city of New York to test the service out. Uber proved to be a hit (Uber.com, n.d.).

\section{0:}

Uber started to work in San Francisco in June 2010. They decided to start in this city because of the lack of taxis and the inexistence of a communication system between the existing taxis. They took advantage of the market problems in order to achieve completely success (Basch, 2016). You could request a car in San Francisco by sending a text or pressing a button. 


\section{1}

In February 2011 Uber closes an $\$ 11$ million Series A funding round that values the company at $\$ 60$ million. Benchmark leads the round, and its partner Bill Gurley joins Uber's board of directors.

In May Uber launches in New York City, one of its biggest and most controversial markets. The application provided nearly 170,000 trips per day between April 2015 and April 2016.

In December Uber starts to expand internationally, starting where the co-founders thought about this idea for the very first time, Paris. It also closes a $\$ 32$ million Series B funding round led by Menlo Ventures, Amazon's Jeff Bezos, and Goldman Sachs (Business Insider, 2016).

\section{2}

In July 2012 Uber unveils its the low-cost Uber X project to the world. The service debuts at 35\% less expensive than the original black cars. This is an innovative movement in order to spread their service to those customers that cannot pay for an expensive service.

In August Lyft, which is considered to be Uber's main competitor launches in San Francisco. Here is where it starts a price war between the two companies in San Francisco (Business Insider, 2016).

\section{3}

In August 2013 Uber moves into India and Africa, and it closes a Series C funding round that sees a $\$ 258$ million investment from Google Ventures. This round values Uber at $\$ 3.76$ billion (Business Insider, 2016).

\section{4}

In April 2014 Uber begins its UberRUSH service, which brings bicycle delivery to Manhattan. The service starts at $\$ 7$, a $\$ 3$ base and $\$ 4$ per mile.

In July of the same year Uber enters in China after raising a $\$ 1.2$ billion funding round at a $\$ 17$ billion valuation in June. China will become Uber's biggest market, and today five out of Uber's 10 largest cities are in China.

In August Uber starts its UberPOOL service, which lets you split the ride and costs with another person who is riding a similar route.

In December Uber raises $\$ 600$ million from Chinese search powerhouse Baidu. Baidu's mobilesearch and maps apps begin to integrate with Uber, and it seems that Uber is gearing up for a fight with other prominent Chinese technology companies (Business Insider, 2016).

\section{5}

In January 2015 Uber rolls out UberCARGO in Hong Kong, which expands Uber's service to include all moving and delivery needs. Uber calls it a way for your goods to "travel like a VIP", and this new feature continues Uber's move in the direction of a logistics company.

In March the company begins the process of buying the mapping startup deCarta, its first acquisition, perhaps to decrease its reliance on Google Maps.

In April they launch UberEATS, an on-demand food-delivery service that brings meals to your location in minutes. The service starts in 4 pilot cities: Los Angeles, Barcelona, Chicago, and New York City. Nowadays it is available in 23 markets in the U.S.

In May the company poaches over 40 employees from Carnegie Mellon University to staff its robotics-research facility, which it opened in February to build self-driving cars. Kalanick has previously mused, "The reason Uber could be expensive is because you're not just paying for the car, you're paying for the other dude in the car". 
In June violent protests erupt across France as taxi drivers and their supporters block roads, burn tires, and attack suspected Uber drivers. Also the Carolina Labor Commission rules that an Uber driver is an employee, not a contractor. This calls Uber's underlying business model into question. The decision comes after a San Francisco driver, Barbara Ann Berwick, files a claim against Uber.

In September Uber's China arm raises $\$ 1.2$ billion to aid in its fight in the China market. Uber's biggest competitor, Didi Kuaidi, responds by raising about $\$ 3$ billion.

In October they launched its UberRUSH program, which had previously been in pilot mode since April 2014 (Business Insider, 2016).

\section{6}

In January 2016 Uber raised another $\$ 2$ billion in private equity funding to continue to help fund its international expansion plans.

In February the company got a $\$ 200$ million investment from Russian billionaire Mikhail Fridman. Also Uber agreed to pay $\$ 28.5$ million to 25 million riders to settle a class-action lawsuit surrounding its advertisements. After the settlement, Uber is no longer allowed to use the terms "industryleading" or "best in class" in reference to its background checks.

In May Uber and ride-hailing competitor Lyft both exited Austin, Texas, after the city's voters backed a measure that would require fingerprint background checks for drivers. Both Uber and Lyft had spent millions working to repeal the city's ordinance, so it was an embarrassing loss for both companies.

In May Uber and Toyota signed a "memorandum of understanding" to explore how the two companies could work together (Business Insider, 2016).

In June the company raised $\$ 3.5$ billion from the Saudi Arabia Public Investment Fund, Uber’s largest investment from a single investor. Yasir Al Rumayyan, managing director of the Public Investment Fund, joined Uber's board. Kalanick also proclaimed that Uber was profitable in hundreds of cities globally, but that that money was being reinvested in its war against Chinese rival Didi. The company said that it is losing $\$ 1$ billion each year in its fight against Didi.

In July the company got another $\$ 1.5$ billion cash infusion, this time in the form of a leveraged loan. The company took advantage of low interest rates and secured a loan that was said to "support Uber's global expansion and operations and invest in research and development and engineering". Uber ran into trouble in Hungary. The company was forced to pull out of the country after government legislation made it impossible for it to operate. The move followed months of protests by taxi drivers. Uber announced in mid-July that it had completed its two billionth trip, just six months after reaching one billion rides. A federal judge ruled that Uber "engaged in fraudulent and arguably criminal conduct" when it used an investigate firm to conduct a background check on a plaintiff in a lawsuit. The plaintiff is accusing Kalanick of violating anti-trust laws by coordinating surge pricing. The Chinese government legalized ride-hailing, paving the way for Uber and Didi to continue their battle for ride-hailing dominance. Didi is already operating in more than 400 cities throughout China, while Uber's goal is to reach 100 cities by the end of the year. Uber's costly battle in China comes to a close as Didi and Uber China merge in a $\$ 35$ billion deal. The merge basically means that Uber has thrown the towel in Chine, likely to the relief of both Didi's and Uber's investors (Business Insider, 2016).

Uber has been always creating new services, in order to cover the needs of their customers. Needs that in the first moment were only to have a transport as fast as possible in the time they wanted using only a smartphone. And through time those needs were changing when the company started to extend their service to people that ride bicycles, people who want food without moving, people who want to send things effectively and efficiently... Uber has always been innovating and improving their service. When they faced a problem, they have tried to solve it by merging or trying to reach an 
agreement. Sometimes the company has failed, but as entrepreneurs they have always looked for opportunities.

\section{PINTEREST}

Pinterest (https://www.pinterest.com) is a platform that allows users to share and save content to virtual collections called pinboards (also referred to as simply "boards"). The social network has both a website and a mobile app, and was launched in 2010 by

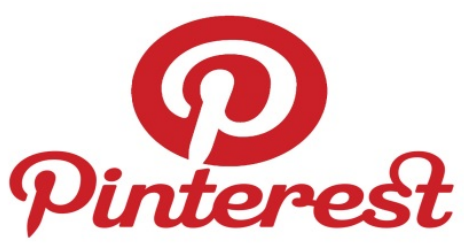
co-founders Ben Silbermann, Evan Sharp, and Paul Sciarra. Initially, the website was available only in a closed beta model, and users could join only by invitation until August 2012, when Pinterest opened to the public (Helmrich, 2016).

If you look to the chart from Google trends (Google Trands, n.d.), which measures how often Google users are searching for certain terms, the

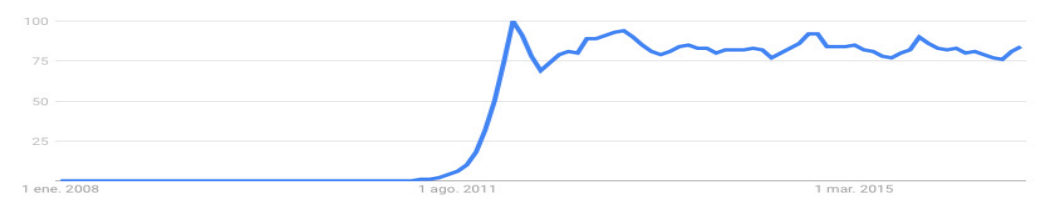
search term "Pinterest" doesn't really register until about midway through 2011. Then it spikes.

But Pinterest was founded in 2008. It had then a different name, a different CEO, and three cofounders (Carlson, 2012).

\section{8}

In August 2008, Paul Sciarra quit his job at New York venture capital firm Radius Capital and his college friend Ben Silbermann quit his job at Google, that was about using data to improve the company's products. They started a company called Cold Brew Labs. There was a third cofounder, but he was a student and he quit the company after a couple weeks to go back to school (Carlson, 2012).

Sciarra was the CEO and his job was to raise money. His home in California was the company's first office. Silbermann was Cold Brew Labs' product visionary from the start and he had a first idea, which was called Tote, and it was an app for the iPhone. It pulled data from online product catalogues to create a meta catalogue for shoppers on the go.

\section{9}

The app was pretty enough and the idea interesting enough, that Cold Brew Labs found institutional funding in early 2009 from First Mark Capital in New York (Carlson, 2012).

Months after launching it was clear that Tote wasn't going to work. There were two big problems. The first one was that people weren't using mobile apps for shopping yet, it was too early. The other was that Apple's App Store wasn't ready to support businesses built on the platform, it was still too slow. Cold Brew Labs would submit an app update to the store and then finish the next version before getting feedback on the prior.

Still, some people were using the app, and most of them were using it in a particular way: they were sending images of particular products to themselves. They were saving the pictures and collecting them. Watching this behavior during the summer of 2009, Silbermann and a very small team of technical employees began working on a product built around this behavior. It would be for the Web, a mature platform. By the end of fall 2009, the new product was almost done. Silbermann had convinced the directors that the new product was the company's future (Carlson, 2012). 


\section{0}

In January 2010 Pinterest completed a round of funding with investors like First Mark Capital, Jeremy Stoppelman, Jack Abraham, Michael Birch... (Crunchbase.com, 2010).

In March the first prototype of the product was launched but it was only available to a small group of colleagues and family members (Carlson, 2012).

In May 31 Shana Fisher, the former IAC M\&A boss, calls the company and says that she loved its product and wants to invest if they would let her (Carlson, 2012).

\section{1:}

In March Pinterest releases an iPhone app that has more than expected number of downloads (Carlson, 2012).

In May 7 the company secures a $\$ 10$ million USD Series A financing led by Jeremy Levine and Sarah Tavel of Bessemer Venture Partners. Other investors include angel investor First Mark Capital, Jack Abraham, Kevin Hartz and Michael Birch. (Crunchbase.com, 2011a; Tsotsis, 2011).

In August 16 Time magazine lists Pinterest in its “50 Best Websites of 2011” article (Number 38) (McCracken, 2011).

In October 7, after an introduction from Kevin Hartz and Jeremy Stoppelman, the company secures $\$ 27$ million USD in funding from Andreessen Horowitz, which values the company at \$200 million USD. Earlier investors First Mark Capital and Bessemer Venture Partners also invest (Crunchbase.com, 2011b; Kincaid, 2011).

\section{2}

In February 20 Pinterest releases a "nopin" HTML meta tag that allowed websites to opt out of allowing their content to be pinned (Yung-Hui, 2012). Then Flickr implements the code to take advantage of this and allow users to opt out of allowing their photos to be pinned (McGee, 2012).

In March Pinterest releases a statement that it believes its use of photos and content in pins is protected by the Digital Millennium Copyright Act's safe harbor provisions (Tsukayama, 2012).

Ben Silbermann, co-founder of Pinterest, appears on stage at the South by Southwest conference on March 13 and announces that revamped profile pages and other product improvements are on their way (Griggs, 2012). And the company decided to eliminate the policy that gives it the right to sell user content. At that time if you receive a notification that a pin has been removed due to a copyright complaint, it means that the Pin's content has been deleted from Pinterest at the request of the content's owner. If your account receives too many copyright complaints, you may lose the ability to Pin new content on Pinterest, and your account may be disabled completely (DesMarais, 2012).

In April 6 the co-founder Paul Sciarra leaves his position at Pinterest for a consulting job as entrepreneur-in-residence at Andreessen Horowitz (Segall, 2012).

In 2012 Pinterest was being used by some politicians as well as public well-known people. For instance, Ann Romney, wife of the 2012 US presidential election candidate Mitt Romney. and Michelle Obama, wife of the president of the United States Barack Obama (Fitzpatrick, 2012; Jennings, 2012).

In May 1 Pinterest continues working on the copyright by adding automatic attribution of authors on images originating from Flickr, Behance, Youtube, and Vimeo. Automatic contribution is also added for Pins from sites mirroring content on Flickr. At the same time Flickr added a Pin shortcut to its share option menu to users who have not opted out of sharing their images (Gannes, 2012).

In May 17 the company secures a $\$ 100$ million USD Series $C$ financing by the Japanese electronic commerce company Rakuten, alongside investors including Slow Ventures, Andreessen Horowitz, 
Bessemer Venture Partners and First Mark Capital, based on a valuation of $\$ 1.5$ billion USD (Crunchbase.com, 2012; Indvik, 2012; Tam, 2012).

In August 10 of 2010 Pinterest no longer requires a request or an invitation to join the site (Owens, 2012). Four days later Pinterest launches apps for Android and iPad (Kerr, 2012).

In September 20 the company hires the new head of engineering, Jon Jenkins, who comes from Amazon, where he spent eight years as an engineering lead, and he was also a director of develop tools, platform analysis and website platform (Taylor, 2012b).

In October 14 the company launches business accounts allowing businesses to either convert their existing personal accounts into business accounts, or start from scratch (Wainwright, 2012).

In October 17 Pinterest announces a new feature that would allow users to report others for negative and offensive activity or block other users if they do not want to view their content. Pinterest said that they want to keep their community "positive and respectful" (Taylor, 2012a).

\section{3}

In January 3 of 2013 Pinterest acquires and announces plans to shut down the recipe discovery site Punchfork, that is like Pinterest but for food (Constine, 2013).

In February 20 the company raises a $\$ 200$ million USD Series D financing at a $\$ 2.5$ billion valuation from Bessemer Venture Partners, Andreessen Horowitz, First Mark Capital and Valiant Capital Partners (Crunchbase.com, 2013a; Taylor, 2013).

In March 20 Pinterest acquires the mobile startup Livestar at undisclosed terms. The company also acquires in October 11 Hackermeter, and the co-founders of Hackermeter, Lucas Baker and Frost $\mathrm{Li}$, join Pinterest as engineers. Hackermeter also shuts down their services (Kumparak, 2013). The acquired companies stopped their former services (Isaac, 2013).

In October 23 Pinterest receives a $\$ 225$ million round of equity (Series E) that valued the website at $\$ 3.8$ billion. Investors include Fidelity Investments, as well as the investors from Series D (Crunchbase.com, 2013b; Reuters, 2013).

\section{4}

In January 6, 2014 Pinterest acquires image recognition and visual search startup VisualGraph (Constine, 2014).

In April 24 the company announces and releases Guided Search for its mobile apps, a new visual way to explore Pinterest's more than 30 billion pins. (Xu, 2014). In June 11 Guided Search is released on the web version of the site (Perez, 2014b; Yin, 2014).

In May 12 Pinterest launches "Promoted Pins" that would allow companies to sponsor results in its search results and category feeds (DeAmicis, 2014; Mott, 2014; Perez, 2014d).

In May 15 the company receives $\$ 200$ million funding (Series F) at a $\$ 5$ billion valuation. Investors include SV Angel, as well as Series E investors (Crunchbase.com, 2014; Hockenson, 2014; Orsini, 2014; Tsotsis, 2014).

In July 30 Pinterest acquires Icebergs, described as a "Pinterest for creatives" by TechCrunch (Perez, 2014a).

In August 30 the company launches a new analytics dashboard for business users (Lawler, 2014), and in October 6 it releases "Pin Picks" that are weekly curations of their own content (Perez, 2014c).

In December 28 Pinterest opens up promoted pins to all advertisers, following what they perceive as success of their beta program (Bradford, 2014; Shu, 2014). 
A comScore study found that approximately 71 percent of Pinterest users in December 2014 were women (Koh, 2015b).

\section{5}

In January 2015 Pinterest debuts new search filters that give users more control over the pins they see. Commentators believe the aim of these is to go after the male demographic, which tends to be put off by the female-heavy pins on the site (Perez, 2015c).

The platform has a unique demographic in that the vast majority of its more that 100 million active users are female (Yeung, 2015).

In January 27 Pinterest announces that it will begin showing Promoted Pins in users' home feeds, thereby expanding the reach of Promoted Pins considerably (Ta, 2015).

In February 11 the company announces a partnership with Apple Inc. whereby people using Pinterest's iOs app on iPhones or iPads can directly download iOS apps from within Pinterest itself, using special types of pins called app Pins (Black, 2015).

In March 16 Pinterest raises a total of $\$ 553$ million (Series $G$ funding) at a $\$ 11$ billion valuation, and allows employees to sell part of their vested stock in secondary markets. It is initially reported that the company has raised $\$ 367$ million, but on May 8 the raising of an additional $\$ 186$ million is announced (DeAmicis, 2015; Kumparak, 2015; Lawler, 2015; Wagner, 2015).

In April 2 Pinterest debuts a new "Pin It" button that requires fewer steps to bookmark a Pin, and that, according to tests, increases the number of pinning actions by $3 \%$. The new button is developed by the team from Icebergs, the company acquires by Pinterest the previous year (Perez, 2015b).

In April 3 Pinterest acquires Hike Labs, a two-person startup developing a mobile publishing application called Drafty, in order to gain technology expertise of the two people. One of them, Jason Shellen, was a founding team member at Blogger and Google Reader as well as a co-founder at Things Labs (Perez, 2015a).

In April 27 the company announces the launch of Marketing Developer Partners (MDP), its program to help marketers use Pinterest more effectively, by helping them schedule pins and incorporate performance feedback to post better pins (Kidwell, 2015; Lafferty, 2015).

In May 4 Pinterest launches the beta version of its developer platform that allows developers to use data about Pinterest users who connect their accounts to external applications (Inkenbrandt, 2015; Lynley, 2015a).

In May 18 Pinterest introduces a new video ad format called Cinematic Pins, where the video plays only either while the user is scrolling or if the user taps on the pin. This is in contrast with existing autoplay videos used by Facebook and other companies for their feeds (Kendall, 2015; Koh, 2015a; Sloane, 2015).

In June 2 the company announces the launch of Buyable Pins with a special type of pin that can be used to make purchases within Pinterest itself. When users select a Buyable Pin, they have the option of choosing the item they wish to buy (for instance, choosing between different dress sizes and colors), and they can make the purchase within the app using a variety of payment methods, including Apple Pay. Launch partners include Shopify and Demandware. The Buyable Pins are free to use, and Pinterest does not take a cut of the purchase made. However, Pinterest intends to allow sellers to promote buyable pins just as they can promote other pins (Novet, 2015; Rao/Fortune, 2015; Wang, 2015).

In June 30 Pinterest begins Rolling out Buyable Pins on iPhone and iPad (Lynley, 2015b).

In July 8 Pinterest rolls out the first integrations on its developer platform (first announced on May $4^{\text {th }}$ ). These include integrations from IFT'T'T and Polyvore (Lynley, 2015c). 
In October 5 Pinterest announces the expansion of Buyable Pins to new partners in addition to its original partner list of Shopify and Demandware. The new partners include Bigcommerce, Magento, and IBM Commerce. Pinterest also notes that there are now 60 million Buyable Pins on the site (Wallace, 2015; Yamartino, 2015).

\section{CONCLUSION}

The objective of the project was to understand the change of entrepreneurial initiatives. Although cases in this paper are based on successful experiences, it may also be useful to contrast a company that failed in the tech sector, and look at why they failed while the others succeeded. We can learn more sometimes from the failures than from the successes.In order to achieve the objective, a comparison has been made of the different terms used over the years and the definition of the term entrepreneur has been completed in order to respond to the creations of new concepts such as markets, companies, technology, innovation, motivation... This comparison has led us to the analysis of some concepts that should be taken into account when referring to entrepreneurial initiative.

The term entrepreneur has been suffering a lot of fluctuations over the years. Although the concept of entrepreneur is relatively new there are a lot of differences between the first definition and the last one.

Through the consulted documentation it has been concluded that nowadays we have to take into account the terms of innovation and motivation in order to analyze a good entrepreneur. One of the main problems for people who want to create a new business or develop a business idea is that they don't have the minimum knowledge needed in order to succeed. This is the main reason why there are some entrepreneurial concepts that should be studied in the school, before university, in order to expand the general knowledge.

In order to analyze how an initiative can be successful, a description of three startups that are having benefits and are growing in the present markets has been provided. The companies are Waynabox, Barkibu, and Lock Up. Making an analysis of the service, the price, the method of innovation, the target market, and the initial investment that they received it can be affirmed that all the companies take a huge advantage of the new technologies and base their business model in services that can be reached only through the internet.

Nowadays in a world of globalization it is easy to develop companies whose services are only for customers through the Internet. Nevertheless, the three companies analyzed only have reached a few years of life. That's the reason why I wanted to make an evaluation of the timeline of some companies that started with an innovative idea in 2008 and are actually valued at billions of USDs. The financial markets at the time as a consequence of the economic crises may have become an opportunity to help these firms offering alternative low cost services. Uber and Pinterest have been chosen, the service of both companies is also based on Internet connections. The study of the timeline has tried to show the problems that were arising when they were trying to develop the company and how they were achieving more and more funds through the years. Both companies started with an idea because of a need that the co-founders where having at a certain time in a certain place. The timeline shows how they dedicated a lot of time and efforts to develop the idea and create a business plan before starting to look for funds.

For the five companies that have been analyzed, a summary of the things the entrepreneurs of the companies took into account when they were initiating the project has been provided.

This project can become a guide for graduated people that do not know how to initiate a business idea, they can learn the things that should be taken into account before, during, and after the development of the business idea.

From our point of view, entrepreneurs are one of the key drivers of the economy in any country. That's the reason why they should be respected and encouraged. In order to have entrepreneurs in a 
country you need to teach as soon as possible the aspects that they will have to face, how they can solve problems, how they can be ethical, and the minimum knowledge needed to innovate.

Education before university should also teach that there are times when certain entrepreneurial initiatives are going to fail, but this doesn't mean that everything is over. The key thing for an entrepreneur is to be able to overcome difficulties, face problems, and keep on going on.

\section{REFERENCES}

Arrieta, E. (2015). Barkibu y el próspero negocio de las mascotas en Internet. [online] Expansión.com. Retrieved 10 Apr. 2016 from http://www.expansion.com/tecnologia/2015/07/31/55ba4815268e3ee9168b459a.html

Barkiadopta.org. (2016). Adopta a una mascota. [online] Retrieved 10 Apr. 2016 from http://www.barkiadopta.org

Barkibu. (2016). Veterinario online gratis - Barkibu. [online] Retrieved 6 Apr. 2016 from http://www.barkibu.com/es

Basch, M. (2016). UBER: De startup a gigante global | Revista Noticias. [online] Noticias.perfil.com. Retrieved 16 Sep. 2016 from http://noticias.perfil.com/2016/03/28/uber-de-startup-a-monopolio-global/

Belarbi, M. (2014). Startup from the bottom: Here is how Uber started out. [online] Gulf Elite. Retrieved 16 Sep. 2016 from http://gulfelitemag.com/startup-bottom-uber-started/

Black, J. (2015). Install the best new iPhone and iPad apps from Pinterest. [online] Pinterest Blog. Retrieved 26 Sep. 2016 from https://blog.pinterest.com/en/install-best-new-iphone-and-ipad-apps-pinterest

Bradford, J. (2014). A big year abead for Promoted Pins. [online] Retrieved 26 Sep. 2016 from https://business.pinterest.com/en/blog/big-year-ahead-promoted-pins

Business Insider. (2016). The story of how Travis Kalanick built Uber into the most feared and valuable startup in the world. [online] Retrieved 16 Sep. 2016 from http://www.businessinsider.com/ubers-history

Cantillon, R. (1755). Essai sur la nature du commerce en général. London: Gyles.

Carlson, N. (2012). Inside Pinterest: An overnight success four years in the making. [online] Business Insider. Retrieved 26 Sep. 2016 from http://www.businessinsider.com/inside-pinterest-an-overnight-success-four-years-inthe-making-2012-4?page $=1$

Centrodeinnovacionbbva.com (2016). Accessed 15 $5^{\text {th }}$ December 2016 from http://www.centrodeinnovacionbbva.com

Constine, J. (2013). Pinterest acquires and will shut down recipe discovery site Punchfork. [online] TechCrunch. Retrieved 26 Sep. 2016 from https://techcrunch.com/2013/01/03/pinterest-acquires-punchfork

Constine, J. (2014). Pinterest acquires image recognition and visual search startup VisualGraph. [online] TechCrunch. Retrieved 26 Sep. 2016 from https://techcrunch.com/2014/01/06/pinterest-visualgraph/

Crunchbase.com. (2010). Jan 1, 2010: Pinterest - Funding RoundAngel. [online] Retrieved 26 Sep. 2016 from http://www.crunchbase.com/funding-round/1a1ea5eacf5093a83ddcd8cf3d58fbd9\#

Crunchbase.com. (2011a). May 7, 2011: Pinterest - Funding Round - Series A. [online] Retrieved 26 Sep. 2016 from http://www.crunchbase.com/funding-round/2478b0af9305549cdb5466114e902f93\#

Crunchbase.com. (2011b). Oct 7, 2011: Pinterest - Funding Round - Series B. [online] Retrieved 26 Sep. 2016 from http://www.crunchbase.com/funding-round/7bdc008a018a708b9816d651bf3150f5

Crunchbase.com. (2012). May 17, 2012: Pinterest - Funding Round - Series C. [online] Retrieved 26 Sep. 2016 from http://www.crunchbase.com/funding-round/83be12d07fa0d616fbb2114153e1b43f

Crunchbase.com. (2013a). Feb 20, 2013: Pinterest - Funding Round - Series D. [online] Retrieved 26 Sep. 2016 http://www.crunchbase.com/funding-round/182b68e6f4b7eab398d4139f6470383f\#

Crunchbase.com. (2013b). Oct 23, 2013: Pinterest - Funding Round - Series E. [online] Retrieved 26 Sep. 2016 from http://www.crunchbase.com/funding-round/7292462dce7dcb2aae071e2c7a7fdcb7\# 
Crunchbase.com. (2014). May 15, 2014: Pinterest - Funding Round - Series F. [online] Retrieved 26 Sep. 2016 from http://www.crunchbase.com/funding-round/316ba090b7e1c4a5cfc785ed1a11e4db\#

DeAmicis, C. (2014). With the launch of paid pins, Pinterest's reckoning moment has arrived. [online] Pando. Retrieved 26 Sep. 2016 from https://pando.com/2014/05/12/with-the-launch-of-paid-pins-pinterests-reckoningmoment-has-arrived/

DeAmicis, C. (2015). Pinterest Adds \$186 Million to Series G Round, Lets Employees Sell Shares. [online] Recode. Retrieved 26 Sep. 2016 from http://www.recode.net/2015/5/8/11562460/pinterest-adds-186-million-toseries-g-round-lets-employees-sell

DesMarais, C. (2012). Pinterest Responds to Concerns, Changes Terms of Service. [online] PCWorld. Retrieved 26 Sep. 2016 from http://www.pcworld.com/article/252515/pinterest responds to concerns changes terms of service.ht $\underline{\mathrm{ml}}$

Encouraging social and commercial entrepreneurship. (2009). Lyon: EMLyon Business School.

Entrepreneur. (2016). In Cambridge Dictionary [online]. Retrieved 2 Apr. 2016 from http://dictionary.cambridge.org/dictionary/english/entrepreneur

European Commission (2004). Plan de acción: El programa europeo en favor del espíritu empresarial. Bruselas.

Fitzpatrick, A. (2012). Michelle Obama joins Pinterest. [online] Mashable. Retrieved 26 Sep. 2016 from http://mashable.com/2012/06/13/michelle-obama-pinterest/\#VfLVjxaxlZq3

Fontinelle, A. (2012). What exactly is a startup? [online] Investopedia. Retrieved 6 Apr. 2016 from http://www.investopedia.com/ask/answers/12/what-is-a-startup.asp

Gannes, L. (2012). Flickr, Behance, Vimeo and YouTube add new Pinterest attribution tool. [online] Retrieved 26 Sep. 2016 from http://allthingsd.com/20120501/flickr-behance-vimeo-and-youtube-add-new-pinterestatttribution-tool//

Gartner, W. B. (1985). A conceptual framework for describing the phenomenon of new venture creation. Academy of Management Review, 10(4), 696-706.

Google Trends. (n.d.). Google Trends. [online] Available at: https://www.google.com/trends/explore?date=200801-01\%202016-09-27\&q=pinterest [Retrieved 27 Sep. 2016].

Griggs, B. (2012). Pinterest: Revamped profile pages, iPad app coming soon [online] CNN. Retrieved 26 Sep. 2016 from http://edition.cnn.com/2012/03/13/tech/web/pinterest-sxsw/index.html

Helmrich, B. (2016). Pinterest for business: Everything you need to know. [online] Business News Daily. Retrieved 26 Sep. 2016 from http://www.businessnewsdaily.com/7552-pinterest-business-guide.html

Hockenson, L. (2014). Pinterest raises $\$ 200$ million in new funding to invest in discovery, monetization. [online] Gigaom.com. Retrieved 26 Sep. 2016 from https://gigaom.com/2014/05/15/pinterest-raises-220-millionseries-e/

Indvik, L. (2012). Confirmed: Pinterest raises $\$ 100$ million to fund international expansion. [online] Mashable. Retrieved 26 Sep. 2016 from http://mashable.com/2012/05/17/pinterest-120-million/\#he6hdtmtQ8qr

Initiative. (2016). In Cambridge Dictionary [online]. Retrieved 2 Apr. 2016 from http://dictionary.cambridge.org/dictionary/english/initiative

Inkenbrandt, J. (2015). Introducing the Pinterest developers platform. [online] Pinterest Engineering. Retrieved 26 Sep. 2016 from https://engineering.pinterest.com/blog/introducing-pinterest-developers-platform

Isaac, M. (2013). Pinterest acquires mobile startup Livestar. [online] Retrieved 26 Sep. 2016 from http://allthingsd.com/20130320/pinterest-acquires-mobile-startup-livestar/?refcat=news

Jennings, N. (2012). Ann Romney joins Pinterest. [online] Washington Post. Retrieved 26 Sep. 2016 from https://www.washingtonpost.com/blogs/election-2012/post/ann-romney-joinspinterest/2012/02/21/gIQAWupkRR blog.html 
Innovating and Entrepreneurial Initiatives

Kendall, T. (2015). New Promoted Pin options to help you reach your goals. [online] Retrieved 26 Sep. 2016 from https://business.pinterest.com/en/blog/new-promoted-pin-options-help-you-reach-your-goals

Kerr, D. (2012). Pinterest debuts device-specific Android and iPad apps. [online] CNET. Retrieved 26 Sep. 2016 from https://www.cnet.com/news/pinterest-debuts-device-specific-android-and-ipad-apps/

Kidwell, J. (2015). Introducing Pinterest's marketing developer partners (MDP). [online] Retrieved 26 Sep. 2016 from https://business.pinterest.com/en/blog/introducing-pinterests-marketing-developer-partners-mdp

Kincaid, J. (2011). Confirmed: Pinterest raises \$27 million round led By Andreessen Horowit:. [online] TechCrunch. Retrieved 26 Sep. 2016 from https://techcrunch.com/2011/10/07/confirmed-pinterest-raises-27-millionround-led-by-andreessen-horowitz/

Kirzner, I. M. (1979) Perception, opportunity and profit. Chicago: University of Chicago Press.

Knight, F. H. (1921). Risk, uncertainty and profit. New York: Houghton Mifflin.

Koh, Y. (2015a). Pinterest bolsters ads with 'cinematic pins'. [online] WSJ. Retrieved 26 Sep. 2016 from http://blogs.wsj.com/digits/2015/05/19/pinterest-bolsters-ads-with-cinematic-pins/

Koh, Y. (2015b). Pinterest's problem: Getting men to commit. [online] WSJ. Retrieved 26 Sep. 2016 from http://www.wsi.com/articles/pinterests-problem-getting-men-to-commit-1421944331

Kumparak, G. (2013). Pinterest acquires coding challenge site Hackermeter right out of the gate, Will shut it down. [online] TechCrunch. Retrieved 26 Sep. 2016 from https://techcrunch.com/2013/10/11/pinterest-acquireshackermeter-right-out-of-the-gate-will-shut-it-down/

Kumparak, G. (2015). Pinterest raises $\$ 367$ Million, Pushing it past $\$ 1$ billion mark. [online] TechCrunch. Retrieved 26 Sep. 2016 from https://techcrunch.com/2015/03/16/pinterest-raises-367-million-pushing-it-past-1billion-raised-in-all/

Lafferty, J. (2015). Pinterest launches marketing developer partners program. [online] Adweek.com. Retrieved 26 Sep. 2016 from http://www.adweek.com/socialtimes/pinterest-launches-marketing-developer-partnersprogram/619444

Lanzadera aceleradora empresas. (2016). Barkibu. [online] Retrieved 6 Apr. 2016 from http://www.lanzadera.es/proyecto/barkibu/

Lanzadera aceleradora empresas. (2015). Waynabox Supera El Medio Millón De Euros En 6 Meses. [online] Retrieved 10 Apr. 2016 from http://www.lanzadera.es/waynabox-supera-medio-millon-euros-6-meses/

Lawler, R. (2014). Pinterest launches a new analytics dashboard for business users. [online] TechCrunch. Retrieved 26 Sep. 2016 from https://techcrunch.com/2014/08/26/pinterest-analytics/

Lawler, R. (2015). Pinterest adds $\$ 186 M$ to series $G$ funding round, Offers secondary sale to employees. [online] TechCrunch. Retrieved 26 Sep. 2016 from https://techcrunch.com/2015/05/09/pinterest-186m-series-gplus-secondary-sale/

Lock Up. (n.d. a). Lock Up actualiza los accesos a tu botel mediante móvil vía bluetooth. [online] Retrieved 15 Sep. 2016 from http://www.lockup.es/en/que-es

Lock Up. (n.d. b). Lock Up hará que tu botel sea más seguro y con más control. [online] Retrieved 16 Sep. 2016 from http://www.lockup.es/en/seguridad

Lynley, M. (2015a). At long last, Pinterest is opening up to developers. [online] TechCrunch. Retrieved 26 Sep. 2016 from https://techcrunch.com/2015/05/04/at-long-last-pinterest-is-opening-up-to-developers/

Lynley, M. (2015b). Pinterest has started rolling out buyable pins on the iPhone and iPad. [online] TechCrunch. Retrieved 26 Sep. 2016 from https://techcrunch.com/2015/06/30/pinterest-has-started-rolling-out-buyable-pinson-the-iphone-and-ipad/

Lynley, M. (2015c). Pinterest rolls out its first development platform integrations. [online] TechCrunch. Retrieved 26 Sep. 2016 from https://techcrunch.com/2015/07/08/pinterest-rolls-out-its-first-development-platformintegrations/ 
McCracken, H. (2011). I just discovered Pinterest on TIME's list of Best Websites. Explore it and more must-see sites on TIME.com. [online] TIME.com. Retrieved 26 Sep. 2016 from http://content.time.com/time/specials/packages/article/0,28804,2087815 2088159 2088155,00.html

McGee, M. (2012). Flicker uses "Nopin" meta tag to keep some images off Pinterest. [online] Marketing Land. Retrieved 26 Sep. 2016 from http://marketingland.com/flickr-uses-nopin-meta-tag-to-keep-some-images-offpinterest-6811

Mill, J. S. (1973). Principles of political economy. Рипол Классик.

Mott, N. (2014). Pinterest emulates Google with new promoted pins. [online] Pando. Retrieved 26 Sep. 2016 from https://pando.com/2014/05/12/pinterest-emulates-google-with-new-promoted-pins/

Novet, J. (2015). Pinterest's new Buyable Pins let you purchase items directly in the app. [online] VentureBeat. Retrieved 26 Sep. 2016 from http://venturebeat.com/2015/06/02/pinterests-new-buyable-pins-let-you-purchaseitems-directly-in-the-app/

Orsini, L. (2014). Pinterest raises A $\$ 200$ million warchest to do battle with Google. [online] ReadWrite. Retrieved 26 Sep. 2016 from http://readwrite.com/2014/05/15/pinterest-funding-5-billion-valuation/

Owens, J. (2012). Bigger than ever, Pinterest opens up to all. [online] The Sydney Morning Herald. Retrieved 26 Sep. 2016 from http://www.smh.com.au/technology/technology-news/bigger-than-ever-pinterest-opens-upto-all-20120810-23yn8.html

Page, V. (2015). Opaque pricing definition. [online] Investopedia. Retrieved 6 Apr. 2016 from http://www.investopedia.com/terms/o/opaque-pricing.asp

Patel, S. (2015). The 17 skills required to succeed as an entrepreneur. [online] Entrepreneur. Retrieved 27 Sep. 2016 from https://www.entrepreneur.com/article/242327

Perez, S. (2014a). Pinterest acquires Icebergs, The Pinterest for creatives. [online] TechCrunch. Retrieved 26 Sep. 2016 from https:/ techcrunch.com/2014/07/30/pinterest-acquires-icebergs-the-pinterest-for-creatives/

Perez, S. (2014b). Pinterest becomes more search engine-like with the launch of guided search on the web. [online] TechCrunch. Retrieved 26 Sep. 2016 from https://techcrunch.com/2014/06/11/pinterest-becomesmore-search-engine-like-with-the-launch-of-guided-search-on-the-web/

Perez, S. (2014c). Pinterest curates its own content with new weekly collections called "Pin Picks". [online] TechCrunch. Retrieved 26 Sep. 2016 from https://techcrunch.com/2014/10/06/pinterest-curates-its-own-contentwith-new-weekly-collections-called-pin-picks/

Perez, S. (2014d). Pinterest launches paid ads with select brands in form of promoted pins. [online] TechCrunch. Retrieved 26 Sep. 2016 from https://techcrunch.com/2014/05/12/pinterest-launches-paid-ads-with-select-brandsin-form-of-promoted-pins/

Perez, S. (2015a). Pinterest acquires team from Hike Labs, including Google Reader, Blogger Veteran Jason Shellen. [online] TechCrunch. Retrieved 26 Sep. 2016 from https://techcrunch.com/2015/04/03/pinterest-acquires-teamfrom-hike-labs-including-google-reader-blogger-veteran-jason-shellen/

Perez, S. (2015b). Pinterest debuts a new "Pin It" button designed to speed up bookmarking. [online] TechCrunch. Retrieved 26 Sep. 2016 from https://techcrunch.com/2015/04/02/pinterest-debuts-a-new-pin-it-buttondesigned-to-speed-up-bookmarking/

Perez, S. (2015c). Pinterest goes after the male demographic with debut of new search filters. [online] TechCrunch. Retrieved 26 Sep. 2016 from https://techcrunch.com/2015/01/23/pinterest-goes-after-the-maledemographic-with-debut-of-new-search-filters/

Rao/Fortune, L. (2015). pinterest wants you to go shopping with new 'Buyable Pins'. [online] TIME.com. Retrieved 26 Sep. 2016 from http://time.com/3905904/pinterest-shopping-buyable-pins/

Reuters. (2013). Pinterest valued at \$3.8 billion in hefty financing deal. [online] Retrieved 26 Sep. 2016 from http://www.reuters.com/article/us-pinterest-fundraise-idUSBRE99M1J520131023

Segall, L. (2012). Pinterest co-founder steps down. [online] CNNMoney. Retrieved 26 Sep. 2016 from http://money.cnn.com/2012/04/03/technology/startups/pinterest-cofounder-steps-down/ 
Innovating and Entrepreneurial Initiatives

Schumpeter, J. A. (1934). The theory of economic development: An inquiry into profits, capital, credit, interest, and the business cycle (Vol. 55). Transaction Publishers.

Shane, S., \& Venkataraman, S. (2000). The promise of entrepreneurship as a field of research. Academy of Management Review, 25(1), 217-226.

Shu, C. (2014). Pinterest will open promoted pins to all advertisers following success of beta program. [online] TechCrunch. Retrieved 26 Sep. 2016 from https://techcrunch.com/2014/12/28/pinterest-will-open-promoted-pins-toall-advertisers-following-success-of-beta-program/

Sloane, G. (2015). Pinterest puts its own spin on video ads with these cinematic pins. [online] AdWeek. Retrieved 26 Sep. 2016 from http://www.adweek.com/news/technology/pinterest-puts-its-own-spin-video-ads-thesecinematic-pins-164854

Ta, A. (2015). An update on Promoted Pins. [online] Pinterest Blog. Retrieved 26 Sep. 2016 from https://blog.pinterest.com/en/update-promoted-pins

Tam, P. (2012). Pinterest raises $\$ 100$ million with $\$ 1.5$ billion valuation. [online] WSJ. Retrieved 26 Sep. 2016 from http://www.wsj.com/articles/SB10001424052702303448404577409212961081738

TAP Portugal. (2016). TAP creative launch. [online] Retrieved 10 Apr. 2016 from http://www.tapportugal.com/Info/en/about-tap/our-company/tap-creative-launch

Taylor, C. (2012a). Pinterest adds ability to block and report other users to keep site 'positive and respectful'. [online] TechCrunch. Retrieved 26 Sep. 2016 from https://techcrunch.com/2012/10/17/pinterest-adds-ability-toblock-and-report-other-users-to-keep-positive-and-respectful//

Taylor, C. (2012b). Pinterest nabs Amazon vet Jon Jenkins to be its new head of engineering. [online] TechCrunch. Retrieved 26 Sep. 2016 from https://techcrunch.com/2012/09/20/pinterest-nabs-amazon-vet-jon-jenkinsto-be-its-new-head-of-engineering/

Taylor, C. (2013). Pinterest confirms massive new $\$ 200$ million Series D funding round and $\$ 2.5$ billion valuation. [online] TechCrunch. Retrieved 26 Sep. 2016 from https://techcrunch.com/2013/02/20/pinterest-confirmsmassive-new-200-million-series-d-funding-round-and-2-5-billion-valuation/

Tsotsis, A. (2011). Pinterest has already pinned down $\$ 10 M$ at a $\$ 40 M$ valuation. [online] TechCrunch. Retrieved 26 Sep. 2016 from https://techcrunch.com/2011/09/15/sources-pinterest-has-already-pinned-down-10m-ata-40m-valuation/

Tsotsis, A. (2014). SV angel leads pinterest financing at a $\$ 5$ billion valuation. [online] TechCrunch. Retrieved 26 Sep. 2016 from https://techcrunch.com/2014/05/15/svangel-leads-pinterests-5-billion-round/

Tsukayama, H. (2012). Pinterest addresses copyright concerns. [online] Washington Post. Retrieved 26 Sep. 2016 from https://www.washingtonpost.com/business/technology/pinterest-addresses-copyrightconcerns/2012/03/15/gIQAijAFES story.html

Uber.com. (n.d.). The Uber story. [online] Retrieved 16 Sep. 2016 from https://www.uber.com/our-story/

Wagner, K. (2015). Pinterest valuation hits \$11 billion with massive new funding. [online] Recode. Retrieved 26 Sep. 2016 from http://www.recode.net/2015/3/17/11560376/pinterest-funding-367-million

Wainwright, C. (2012). Pinterest finally rolls out business accounts: How to set yours up today. [online] Blog.hubspot.com. Retrieved 26 Sep. 2016 from http://blog.hubspot.com/blog/tabid/6307/bid/33839/Pinterest-FinallyRolls-Out-Business-Accounts-How-to-Set-Yours-Up-Today.aspx\#sm.001g50ra81bfue3ew0n2azdac813y

Wallace, T. (2015). Introducing Pinterest buyable pins for Bigcommerce retailers. [online] The BigCommerce Blog. Retrieved 26 Sep. 2016 from https://www.bigcommerce.com/blog/introducing-pinterest-buyable-pins-forbigcommerce-retailers

Wang, C. (2015). Coming soon: Buyable Pins!. [online] Pinterest Blog. Retrieved 26 Sep. 2016 from https://blog.pinterest.com/en/buyable-pins

Waynabox. (n.d.). 1 ciudad secreta. Vuelos + alojamiento por 150€. [online] Retrieved 27 Sep. 2016 from https://waynabox.com/es/

Wanabox (2016). Dossier informativo. Waynabox internal document. 
Xu, H. (2014). Guided search: A new way to find what you're looking for. [online] Pinterest Blog. Retrieved 26 Sep. 2016 from https://blog.pinterest.com/en/guided-search-new-way-find-what-you $\% \mathrm{E} 2 \% 80 \% 99$ re-looking

Yamartino, M. (2015). New merchants and platforms for Buyable Pins. [online] for Business. Retrieved 26 Sep. 2016 from: https://business.pinterest.com/en/blog/new-merchants-and-platforms-buyable-pins

Yeung, K. (2015). Pinterest finally shares its siz̨e: $100 \mathrm{M}$ monthly active users and counting. [online] VentureBeat. Retrieved 26 Sep. 2016 from http://venturebeat.com/2015/09/16/pinterest-finally-shares-its-size-100mmonthly-active-users-and-counting/

Yin, Y. (2014). Guided Search hits the web!. [online] Pinterest Blog. Retrieved 26 Sep. 2016 from https://blog.pinterest.com/en/guided-search-hits-web

YouTube. (2016). Barkibu, la nueva app de consulta veterinaria online. [online] Retrieved 10 Apr. 2016 from https://www.youtube.com/watch?v=Z-ifeFOboSc

Yung-Hui, L. (2012). Forbes Welcome. [online] Forbes.com. Retrieved 26 Sep. 2016 http://www.forbes.com/sites/limyunghui/2012/02/21/pinterest-introduces-nopin-to-counter-copyrightconcerns/\#5fba79852137

\section{BIOGRAPHIES}

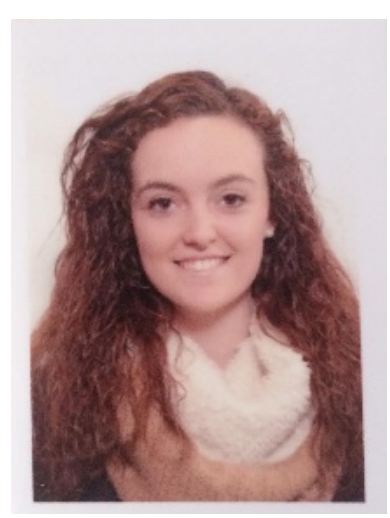

Marta Machin Martínez studied Business Administration and Management in the Rey Juan Carlos University in Madrid. She performed two Erasmus + mobility programmes in the Hanzehogeschool University of Applied Sciences in Groningen (The Netherlands) and in the Université Catholique de Lyon (France). She finished her business degree making an international internship in Saint Étienne (France). She started working in the advisory company Management Solutions in the Human Resources department as a financial trainee and she is currently working in KPMG as a consultant trainee in the Financial Management department.

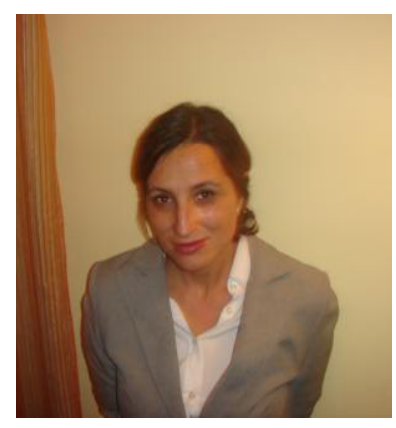

Carmen de Pablos, PHD, is a Professor in the Business Administration Area at the Rey Juan Carlos University in Madrid (URJC), Spain from 1994. Instructor at Norwich University from 2012. She is responsible for the PhD in Business Administration at URJC. She is specialized in the impact of information technologies over organizational systems where she develops main research. She has chaired Doctoral Dissertations and Projects on the impact of information and communication technologies in organizational performance. She has presented communications in different international venues and has published 125 articles in specialized and indexed journals and 12 books and chair or 22 Doctoral Dissertations and 22 competitive projects. She has also worked as a consultant in the area of IS management at Prima Consulting. She is the Academic Director for the Master's Degree and Doctoral program in Business Administration and Entrepreneurship at the Rey Juan Carlos University and the co-director of the Master's Degree in Project Management, SAP-ERP Systems, Editor or the Academic Review ESIC-Market from July 2016. 